\title{
On Status and Game of Three Political Powers Involved in "Su Bao Case"
}

$$
\text { Le } \mathrm{MA}^{1, *} \text {, Ying-qi } \mathrm{WU}^{2} \text {, }
$$

${ }^{1}$ School of Political Science and Public Administration,University of Electronic Science and Technology, Chengdu, Sichuan Province, China.

${ }^{2}$ School of Political Science and Public Administration,University of Electronic Science and Technology, Chengdu, Sichuan Province, China.

*1616091978@qq.com,

\begin{abstract}
Su Bao case" was an extremely important case in the history of China's modern journalism. From its occurrence to its trial and sentence, "Su Bao case" was not just a case about news speech, but implied the contest among various political powers. In "Su Bao case", the differences of strength of the three major political powers - the intellectuals running newspapers, the Qing government and foreign powers and their contests and compromises for interests can be clearly seen through their strategies and acts. Therefore, through the analysis of status and game of three political powers in "Su Bao case", this paper could give us a deeper understanding of news and journalism development of China at that time.
\end{abstract}

Keywords: "Su Bao case", political forces,game

\section{The Background and Brief Introduction of "Su Bao Case"}

Under the charge of Chen Fan, whose political stand gradually transferred to revolutions for increasingly frequent contact with patriotic intellectuals of Educational Association of China and Patriotic Academic Society in Shanghai and gradual influence form revolutionary thoughts, Su Bao's political stand also began to transfer.

In May 1903, Zhang Shizhao served as the chief writer of Su Bao. Thus, Su Bao began to publish a large number of articles with fiery rhetoric to disseminate revolutionary ideas and denounce the autocracy of Qing Dynasty. For example, it introduced Zou Rong's Revolutionary Army and Zhang Taiyan's The Relationship Between Kang Youwei and Emperor Jueluo, and published Zhang Shizhao's commentary articles On "Revolutionary Army" and How Freak the Manchu and Han Students Are. From then on, Su Bao started to openly advocate revolutions, express its support for students' patriotic movements and vigorously attack the Qing government's corruption and incompetence.

In June 1903, articles published in the column of "Introduction of New Books" of Su Bao advocated revolutions and called Emperor Guangxu by "Zaitian the Clown", which made the Qing government intolerable. On June 30, the Qing government consulted with Consulate Generals of Shanghai to arrest Chen Fan, Zhang Taiyan and Zou Rong by the Municipal Council. On July 7, Su Bao was closed down. A pretrial was made on July 14, and formal court trial on December 3. On December 9, the Chinese official Wang Yaoting preempted to make a sentence. However, the British Vice-consul made a protest against the sentence and refused to recognize the validity of the unilateral sentence by the Chinese official, because he didn't consult with Britain in advance and the sentence was too heavy. They didn't reach an agreement until May 21, 1904 when they made a compromise, and made final sentences that Zhang Taiyan was imprisoned for 3 years and Zou Rong for 2 years, and Su Bao would be stopped forever. 


\section{The Status of Different Political Powers in "Su Bao Case"}

In the modern history of China, "Su Bao case" was not just a case of newspaper running, but also concerned with the balance of power and structures of China's political powers in the field of news and information, which had great significance for understanding and studying news and media under the social background of that period.

\subsection{Intellectuals: Weak but Radical}

In "Su Bao case", the intellectuals running newspapers such us Zhang Taiyan and Zou Rong fiercely criticized and attacked the Qing government, showing their high morale and spirit. But under the social environment of that period, they were actually a disadvantaged group and were suppressed soon. In the later part of the trial, they also changed their passionate fighting spirit and avoided mentioning revolution to save themselves, which reflected their weakness from another aspect.

\subsubsection{Radical Political Viewpoints}

Compared with previous reformists of landlord class, bourgeois reformers and royalists, the political viewpoints of the intellectuals running newspaper in the "Su Bao case" represented by Zhang Taiyan and Zou Rong were more radical and more profound. With the further development of newspapers in modern China, their strong demand for political reform and political rights also had more adequate carriers and broader platforms. The development of this dual history increasingly strengthened the public political function of newspapers in modern China on the whole.

The public political function of newspaper in modern China was gradually strengthened, and so was its interference with and intervention in the national politics, but the living of intellectuals running newspapers, who stood behind the newspapers of modern China, or who controlled ideological dynamics and trends of newspapers, was in a relatively fragile and insecure state. Zhang Taiyan and Zou Rong involved in "Su Bao case" became intellectuals running newspapers with a rather unique style during that period and their living state typically represented that of intellectuals running newspapers at that time.

Su Bao's standpoint of propaganda changed after Chen Fan took charge of it. It began to propagate reform and constitutionalism, and then its standpoint tended to revolution with the development of revolutions in China. Su Bao started to openly publish articles and reports directly related to AntiQing Dynasty or revolution particularly after Zhang Taiyan became the chief writer on May 27, 1903. It stated current affairs, commented on political situation, and propagated various plans and proposals about China's reform and revitalization with radical rhetoric.

\subsubsection{Fragile Living Environment}

On the other hand, it can be seen that the intellectuals running newspapers such as Zhang Taiyan, Zou Rong and Chen Fan were in a fragile situation and at a low political status from "Su Bao case". At that time, as a semi-feudal and semi-colonial country, China was in a complex network of powers restricting each other due to the cross-penetration of powers from the autocratic government and foreign forces. As a result, China lacked a set of government operation mechanism and legal system that were stable, perfect and consistent with the spirit of rule of law under that kind of national conditions.

These were definitely severe challenges for intellectuals who were running newspapers then. In "Su Bao case", intellectuals such as Zhang Taiyan and Zou Rong were exempted from the tragic fate of literary inquisition like those living in the previous feudal dynasties, but they still could not escape form doom under the peace of the Qing government and foreign powers. In the mutual compromise and conspiracy of Sino-foreign powers, this incident eventually ended up with the verdict: "these two people are of the same evil and their crime can not be forgiven or considered. Zou Rong was sentenced 
for two-year imprisonment and Zhang Binglin three-year imprisonment. And they shall be amerced to drudge for warning others and deported from the Settlement after their expiration of imprisonment".

\subsection{The Qing Government: a "Law-abiding" Government}

Literary inquisition was an important means for successive feudal dynasties to suppress the thoughts of intellectuals, and they often conducted severe, cruel and direct suppression and persecution. However, the Qing government took a relatively normative legal procedures and means in the whole "Su Bao case", showing an unprecedented "law-abiding" attitude towards such problems.

The Qing government took a weak and even blank charge in the domestic newspapers due to foreign powers. China was in a semi-colonial and semi-feudal environment at that time, so the supervision of domestic affairs from autocratic central regime was greatly influenced by foreign settlements, embassy districts and some special historical circumstances like the loss of extraterritoriality of the central government. This was the political roots for Qing government to handle the "Su Bao case" in a "law-abiding" way. In other words, the special structure of political power in China at that time restricted and even determined the approach the Qing government took to handle the "Su Bao case".

"Su Bao case is of great historic significance. Its positive influence is that revolutionaries, just at the cost of a newspaper office, sharply attacked the Qing government by public opinion and made its heyday majesty of ruthless means burning books and burying the literati in pits vanish completely." Objectively speaking, the Qing government took a "law-abiding" means that was helpless but relatively consistent with democracy and the rule of law in the whole "Su Bao case". But meanwhile the Qing government was in a relatively unfavorable condition.

\subsection{Foreign Powers: the Third Party but Not Neutral}

The reaction of foreign powers represented by Britain was concordant to some degree in "Su Bao case", which also reflected the consistency of foreign powers in China for seeking interests from another aspect.

Firstly, the foreign powers seemed to play a third neutral part in "Su Bao case" on the surface. But actually in the process of trial, the Western powers were everywhere from the appointment of bilateral lawyers, to the selection of trial court, and to the composition of the court and the laws and regulations the trial based on. Therefore, in order to safeguard its interests in China, the foreign powers did not play a neutral third-party political role in "Su Bao case".

There was no doubt that all the rights shared in the Settlement were based on the interests' maintenance of the British and American Settlements. In this way, the foreign powers required the puppet Qing government not to harm their interests, but they could not suppress the Qing government too much in this premise. When the Qing government made a requirement of extraditing relevant people involved in "Su Bao case" from the foreign powers in the Settlement, who must judge and weigh their interests in China. One of the key issues was extraterritoriality, that is, if the foreign powers in the Settlement agreed on the Qing government's requirement of extradition, it meant that the Settlement lost its "independent" judicial status, and in the future related issues, the power of the Qing government would probably penetrate again into the Settlement, which would frustrate the government of foreign powers in China and lose their profits.

\section{Political Game in "Su Bao Case"}

Three kinds of different political powers of intellectuals, the Qing government and foreign powers interdigitated together and held diverse proposals and claims in "Su Bao case", so it is a complicated 
and intricate competition of these three political powers.

\subsection{Persecution from Attack: Intellectuels and the Qing Government}

The Qing government was resentful on the reckless attack from $S u B a o$, so various means were taken to prosecute the staff in $\mathrm{Su} B a o$ and break down the newspaper. The government claimed that " $\mathrm{Su}$ $B a o$ incites people to rise in rebellion, defames our forefathers and the saints and even criticizes their ideas, which is very evil deeds in history and must be cracked down." It clearly showed that the Qing government resented and feared what $\mathrm{Su}$ Bao published. In the late June of 1903, after ploting and planning, the Qing government ultimately laid murderous hands on Su Bao. And new-type intellectuals Zhang Taiyan and Zou Rong were put into prison, suffering persecution.

\subsection{Disagreement Within Agreement: the Qing Government and Foreign Powers}

Registered in Shanghai International Settlement, "Su Bao case" mainly resulted from intellectuals' criticism on the Qing government and broke out in the Settlement, in which the foreign powers' jurisdiction in China was involved. Therefore, the handling of this case must be involved in the interests game of both sides. And also, centered around the Municipal Council, the Qing government had contradictions and conflicts with the consular groups, ambassadors in China, and foreign powers from UK government. However, Due to the common interest of Qing government's autocracy and foreign countries' interests in China, both sides tended to reach an agreement for the balance of their interests.

Faced with overlapping resistances, the Qing government was forced to forsake its plan to catch and extradite the Su Bao defendants including Zhang and Zou in the Shanghai International Settlement. However, foreign powers against the Qing government this time was not to protect Zhang and Zou but for their privilege of "extraterritoriality" in China and an important bargaining chip for expanding their interests in China.

It is clearly that The Municipal Council rather the Qing government nor both Zhang and Zou played a critical role in this case which represented the foreign powers' interests. Preventing overly suppressing or undermining the Qing government's power for maintaining their relationship, foreign powers made compromise with the Qing government in the trial of the case and reached an agreement in the end. Although they once committed that both Zhang and Zou were innocent to freely publicize their opinions, they made the final sentence: Zhang Binglin was imprisoned for three years; the other, Zou Rong, was imprisoned for two years and to drudge expired after the expulsion of the Settlement. Since then, $\mathrm{Su}$ Bao was closed to the end.

\subsection{Win-win Outcome Created by Times: the Intellectuals and Foreign Powers}

Boundary of power between foreign powers and the Qing government created a relatively open and safe environment for the Chinese newspaper intellectuals to exercise in some degree. In "Su Bao case", there was an absence of distinctly direct connection or political corporation and contest between the intellectuals and foreign powers, from which they both benefited only from the perspective of gaining interest and reputation.

At that time, China's social power structure was complex and distinguished. On one hand, due to the intervention of foreign power, the Qing government lost absolute control over China, failing to deal with those affairs involved with foreign powers. On the other hand, it was imperative for foreign powers to resolutely maintain their exclusive right in China as well as depend on regular operation of their puppet government to protect their interest in China without overly neglecting the government's reaction. In such environment with interlaced powers, a power weakening belt emerged in which both China and foreign powers offset and compromised to each other. 
It made both intellectuals and foreign powers benefit in this case objectively. For example, Chen Fan, Zhang Taiyan and Zou Rong were sentenced to two-three years in prison, prevented from being directly executed or life imprisonment claimed by the Qing government because of literary inquisition due to offending the feudal sovereignty. As what Lu Xiaona said, Western powers' dominated position in the trail contest with the Qing government sheltered the involved and prevented them from being cruelly penalized by the Qing government. At the same time, western powers achieved their goals to maintain and consolidate their privileges in China with consistency and inviolability. However, this case indeed reflected Chinese government's weakening controlling over domestic affairs and the turmoil of society.

\section{References}

[1] Fang Hanqi, edit. Comprehensive Chinese Journalism History, Volume One [M]. China Renmin University Press, 1992.09: 737.

[2] Hu Daojing. Shanghai's Daily Paper, contained Yang Guanghui et al, edit. An Overview of Chinese Modern Newspaper Development, Xinhua Publishing House, 1986: 331.

[2] Zhang Taiyan. Selections of Zhang Taiyan's Political Comments, Volume One[M]. Zhonghua Book Company, 1977: 238.

[3] Morrison. The Inside Political Stories of the Late Qing Dynasty [ Z ]. Luo Huimin, edit. Liu Jiake et al, trans. World Affairs Press, 1986:289.

[4] Zhou Yonglin,edit. A Collection of Zou Rong [A]. Chongqing Dateset of Local History, 1982:61.

[5] Preface to Revolutionary Army, published on June 9,1903 on Su Bao.

[6] Wang Min. Study on "Su Bao Case" [M]. Shanghai: Shanghai People's Publishing House, 2010: 09.

[7] Zhang Kaiyuan, Lin Zengping, major editors. History of Revolution in 1911, Volume One [M]. People's Publishing House, 1980:403.

[8] Lu Xiaona. Reflection to Competition Between China and Western Powers Based on the Trail to Zhang Taiyan and Zou Rong [J]. Social Science Edition of the Journal of Taiyuan University of Technology, 2012.10,30(05). 